\title{
Faktor-Faktor yang Berhubungan Dengan Kejadian Penyakit Batu Saluran Kemih Pada di Poli Urologi RSAU dr. Esnawan Antariksa
}

\author{
*Martha K. Silalahi \\ Program Studi Sarjana Keperawatan, Fakultas Kesehatan, \\ Universitas Mohammad Husni Thamrin
}

Corresponden author: martha766hi@gmail.com

Received : Agust 7, $2020 \quad$ Accepted : September 25, $2020 \quad$ Published: September 30, 2020

DOI: https://doi.org/10.37012/jik.v12i2.385

\begin{abstract}
Urinary tract stone disease is a disease that is suffered by many people in the world. The formation of urinary stones is influenced by intrinsic factors (age, family history of urinary tract stones and gender) and extrinsic factors (geography, climate and temperature, fluid intake, diet, occupation, stress, obesity (obesity), holding back urine). The research objective was to determine the relationship between the independent variables, age, family history, gender, fluid intake, length of sitting while working and obesity with the dependent variable, namely the incidence of urinary tract stones in patients in the Urology Department of RSAU dr. Esnawan Antariksa. The study uses descriptive correlational with a correlational approach, the number of samples is 32 people with the simple random sampling technique. The results obtained from the risk factors for urinary tract stones that proved significant were age ( $p$-value 0.003), family history ( $p$-value 0.025), gender ( $p$-value 0.035), fluid intake ( $p$-value 0.003). ), length of sitting while working ( $p$-value 0.035). This study can determine that from the risk factors for urinary tract stones including age, family history of urinary tract stones, gender, fluid intake, length of sitting while working and obesity have an effect on the incidence of urinary tract stones.
\end{abstract}

Keyword: Urinary Tract Stone, Risk Factors, Urinary Tract Stone Patient.

\begin{abstract}
ABSTRAK
Penyakit batu saluran kemih adalah penyakit yang banyak di derita oleh penduduk di dunia. Pembentukan batu saluran kemih di pengaruhi oleh faktor intrinsik (usia, riwayat keluarga menderita batu saluran kemih dan jenis kelamin) dan ekstrinsik (geografi, iklim dan temperatur, intake cairan, diet, pekerjaan, stres, kegemukan (obesitas), kebiasaan menahan buang air kemih). Tujuan penelitian ini untuk mengetahui hubungan antara variabel independen yaitu usia, riwayat keluarga menderita batu saluran kemih, jenis kelamin, intake cairan, lama duduk saat bekerja dan obesitas dengan variabel dependen yaitu kejadian batu saluran kemih pada pasien di ruang Poli Urologi RSAU dr. Esnawan Antariksa. Penelitian ini menggunakan deskriptif korelasional dengan pendekatan korelasional, Jumlah sampel 32 orang dengan teknik Simple Random Sampling. Hasil yang diperoleh dari penelitian ini faktor - faktor risiko kejadian batu saluran kemih yang terbukti secara signifikan adalah usia ( $\mathrm{p}$ value 0,003 ), riwayat keluarga (p-value 0,025$)$, jenis kelamin ( $\mathrm{p}$-value 0,035 ), intake cairan ( $\mathrm{p}$-value 0,003), lama duduk saat bekerja (p-value 0,035). Penelitian ini dapat disimpulkan bahwa dari faktor faktor risiko kejadian batu saluran kemih yang meliputi usia, riwayat keluarga menderita batu saluran kemih, jenis kelamin, intake cairan, lama duduk saat bekerja dan obesitas berpengaruh terhadap kejadian batu saluran kemih.
\end{abstract}

Kata Kunci : Batu Saluran Kemih, Faktor Risiko, Pasien Batu Saluran Kemih. 


\section{PENDAHULUAN}

Batu saluran kemih (BSK) atau Urolithiasis adalah suatu kondisi dimana dalam saluran kemih individu terbentuk batu berupa kristal yang mengendap dari urin (Mehmed \& Ender, 2015). Urolithiasis adalah suatu keadaan terjadinya penumpukan oksalat, calculi (batu ginjal) pada ureter atau daerah ginjal (Nuari \& Widayati, 2017, p. 197). Batu saluran kemih (urolithiasis) merupakan obstruksi benda padat pada saluran kencing yang terbentuk karena factor presipitasi endapan dan senyawa tertentu. Batu tersebut bisa terbentuk dari berbagai senyawa, misalnya kalsium oksalat (60\%), fosfat (30\%), asam urat (5\%) dan sistin $(1 \%)$ (Prabowo \& Pranata, 2014, p. 111).

Angka kejadian pada penyakit batu saluran kemih diperkirakan sebesar $13 \%$ pada laki-laki dewasa dan 7\% pada perempuan dewasa. Pada negara maju seperti Amerika Serikat ditemui sekitar 5-10\% penduduknya pernah menderita penyakit batu saluran kemih, di Eropa Utara ditemui 3-6\%, sedangkan di Eropa bagian Selatan ditemui sekitar 6-9\% kasus. Di Jepang ditemui sekitar 7\% kasusnya dan di Taiwan ditemui sebanyak 9,8\% (Wardani, 2014). Tidak hanya di dunia tetapi di Asia pun mempunyai angka kejadian batu saluran kemih mencapai 15\%. Selain itu juga banyak ditemukan kasus batu saluran kemih di negara-negara berkembang, seperti India, Thailand dan Indonesia yang angka kejadiannya sekitar 2-15\% biasa di jumpai karena ada hubungannya dengan perkembangan ekonomi dan peningkatan pengeluaran biaya untuk kebutuhan makanan perkapita.

Di Indonesia sendiri, angka kejadian batu saluran kemih yang sesungguhnya masih belum bisa diketahui secara pasti, tetapi diperkirakan terdapat 170.000 kasus per tahunnya (Buntaram, Trusda, \& Dananjaya, 2014). Di Jawa Barat, menurut Riskesdas tahun 2013, bahwa prevalensi angka kejadian batu saluran kemih $\geq 15$ tahun berdasarkan diagnosis dokter, Jawa Barat berada di urutan ke 5 dari 33 provinsi di Indonesia, bukti ini membuktikan bahwa angka kejadian kasus pada batu saluran kemih masih tinggi (Riskesdas, 2013 dalam Buntaram, Trusda, \& Dananjaya, 2014).

Berdasarkan penelitian yang dilakukan oleh Hidayah, Nugroho \& Widianto (2013) di RSKB An Nur Yogyakarta, sampel yang diperoleh berdasarkan kriteria inklusi adalah pasien dengan batu saluran kemih dengan distribusi penelitian laki-laki dibanding perempuan sebesar 4,7 : 1 (33 laki-laki dan 7 orang perempuan), distribusi umur subjek penelitian dari yang tertinggi hingga terendah yaitu usaia 40-49 tahun (37\%), usia 50-59 tahun (25\%), usia 30-39 tahun (20\%), usia 60-69 tahun $(7,5 \%)$ dan usia $<30$ tahun serta $>69$ tahun masing-masing $(5 \%)$. 
Adapun lokasi terjadinya batu saluran kemih proksimal dibandingkan batu saluran kemih distal (27:13). Jumlah batu saluran kemih pada dekstra sama dengan batu saluran kemih pada sinistra dengan proporsi batu saluran kemih proksimal dekstra lebih banyak dibanding batu saluran kemih proksimal sinistra (16:11).

Berdasarkan penelitian yang dilakukan oleh Wendi (2016) di RSUD Pasar Rebo Jakarta Timur, sampel yang di peroleh sebanyak 41 pasien dengan menggunakan tehnik Purvosive Sampling. Hasil dari penelitian ini menyimpulkan bahwa dari faktor keturunan dan penyakit metabolisme tidak berpengaruh terhadap kejadian batu ginjal tetapi kejadian batu ginjal lebih kepada faktor ekstrinsik yaitu geografi, iklim, temperatur, lama duduk, kurang minum dan diet tinggi protein. Sebagai upaya pencegahan terhadap timbulnya kembali penyakit batu saluran kemih yang disebabkan oleh faktor-faktor yang mempengaruhi tersebut, salah satunya dengan cara melakukan promosi kesehatan diantaranya: perawat yang berperan sebagai edukator, perawat dapat memberikan pendidikan kesehatan terkait dengan faktorfaktor risiko yang berhubungan dengan kejadian penyakit batu saluran kemih dan bagaimana mencegah serta menanganinya.

Berdasarkan data studi pendahuluan yang didapat di RSAU dr. ESNAWAN ANTARIKSA didapatkan 588 pasien yang menderita batu saluran kemih (Juni 2018 - Juni 2019) yang terjadi, serta adanya pendapat dan hasil penelitian yang berbeda tentang faktor-faktor kejadian batu saluran kemih, maka penulis tertarik untuk meneliti tentang apakah terdapat hubungan antara faktor-faktor risiko batu saluran kemih dengan angka kejadian batu saluran di ruang Poli Urologi.

\section{METODE PENELITIAN}

Penelitian ini bersifat deskriptif korelasional dengan desain cross sectional dengan menggunakan teknik simple random sampling. Sampel penelitian ini sebanyak 32 responden pasien dengan batu saluran kemih, dan menggunakan instrumen penelitian dengan kuesioner dan lembar observasi. 


\section{HASIL \& PEMBAHASAN}

\section{Analisis Univariat}

Jumlah responden yang diperoleh sebanyak 32 responden. Hasil analisis univariat terdiri dari usia, jenis kelamin, riwayat keluarga menderita batu saluran kemih, intake cairan, lama duduk saat bekerja dan obesitas. Hasil penelitian ini menunjukkan:

Tabel 1

Distribusi Frekuensi Responden di Poli Urologi RSAU dr. Esnawan Antariksa

\begin{tabular}{clcc}
\hline No & \multicolumn{1}{c}{ Variabel } & Frekuensi $(\boldsymbol{f})$ & Persentase $(\%)$ \\
\hline 1 & Usia & 28 & \\
& Lansia awal - Manula & 4 & 87,5 \\
& Dewasa awal - Dewasa akhir & & \\
\hline 2 & Jenis Kelamin & 29 & 90,6 \\
& Laki - laki & 3 & 9,4 \\
& Perempuan & 25 & 78,1 \\
\hline 3 & Riwayat Keluarga & 7 & 21,9 \\
& Ada riwayat & & \\
& Tidak ada riwayat & 28 & 87,5 \\
\hline 4 & Intake cairan & 4 & 12,5 \\
& $<1500$ ml & & \\
& $>$ 1500 ml & 29 & 90,6 \\
\hline 5 & Lama Duduk saat bekerja & 3 & 9,4 \\
& $>$ 4 jam/hari & & 87,5 \\
& $<4$ jam/hari & 28 & 12,5 \\
\hline 6 & Obesitas & 4 & 87,5 \\
& $>$ 25, obesitas & & 12,5 \\
\hline 7 & Kejadian BSK & 28 & \\
& Ada batu & 4 & \\
& Tidak ada batu & & \\
\hline
\end{tabular}

Berdasarkan tabel 1 dapat dijelaskan bahwa dari 32 responden, sebanyak 28 orang $(87,5 \%)$ yang mengalami kejadian batu saluran kemih adalah usia lansia awa - manula, sedangkan dengan usia dewasa awal - dewasa akhir yang mengalami sebanyak 4 orang (12,5\%). Faktor Jenis kelamin yang banyak mengalami kejadian batu saluran kemih adalah laki-laki sebanyak 29 orang $(90,6 \%)$ sedangkan perempuan sebanyak 3 orang $(9,4 \%)$. Faktor Intake cairan < $1500 \mathrm{ml}$ ada sebanyak 28 orang $(87,5 \%)$ dan yang > $1500 \mathrm{ml}$ sebanyak 4 orang (12,5\%). Faktor Lama duduk saat bekerja > 4 jam/hari sebanyak 29 orang $(90,6 \%)$ dan $<4$ jam/hari sebanyak 3 orang $(9,4 \%)$. Faktor Obesitas $>25$ sebanyak 28 orang $(87,5 \%)$ dan yang $<25$ sebanyak 4 orang (12,5\%). Pada kejadian batu saluran kemih dengan ada batu sebanyak 28 orang $(87,5 \%)$ dan yang tidak ada batu sebanyak 4 orang $(12,5 \%)$. 


\section{Analisis Bivariat}

Analisis bivariat yang dilakukan pada penelitian ini yaitu dengan menghubungkan variabel independen yaitu: umur, jenis kelamin, riwayat keluarga menderita batu saluran kemih, intake cairan, lama duduk saat bekerja dan obesitas.

Tabel 2.

Hubungan Usia, Jenis Kelamin, Riwayat Keluarga, Intake Cairan , Lama duduk Saat Bekerja, Obesitas Dengan Kejadian Penyakit Batu Saluran Kemih pada Pasien di Ruang Poli Urologi RSAU dr. Esnawan Antariksa

\begin{tabular}{|c|c|c|c|c|c|c|c|c|}
\hline \multirow{3}{*}{ Variabel } & \multicolumn{8}{|c|}{ Kejadian Penyakit Batu Saluran Kemih } \\
\hline & \multicolumn{2}{|c|}{ Ada batu } & \multicolumn{2}{|c|}{$\begin{array}{c}\text { Tidak ada } \\
\text { batu }\end{array}$} & \multicolumn{2}{|c|}{ Jumlah } & \multirow{2}{*}{$\begin{array}{c}\mathbf{P} \\
\text { value }\end{array}$} & \multirow[t]{2}{*}{ OR } \\
\hline & $\mathbf{n}$ & $\%$ & $\mathbf{n}$ & $\%$ & $\mathbf{n}$ & $\%$ & & \\
\hline Usia & & & & & & & & $81,000(3,963-$ \\
\hline Lansia awal - Manula & 27 & 96,6 & 1 & 3,6 & 28 & 87,5 & 0,003 & $1655,753)$ \\
\hline Dewasa awal - Dewasa akhir & 1 & 25 & 3 & 75 & 4 & 12,5 & & \\
\hline Jenis Kelamin & & & & & & & & $27,000(1,646-$ \\
\hline Laki - laki & 27 & 93,1 & 2 & 6,9 & 29 & 90,6 & 0,035 & $422,833)$ \\
\hline Perempuan & 1 & 33,3 & 2 & 66,7 & 3 & 9,4 & & \\
\hline Riwayat Keluarga & & & & & & & & 18,000 \\
\hline Ada riwayat & 24 & 96 & 1 & 4 & 25 & 78,1 & 0,025 & $(1,480-218,950)$ \\
\hline Tidak ada riwayat & 4 & 57,1 & 3 & 42,9 & 7 & 21,9 & & \\
\hline Intake cairan & & & & & & & & 81,000 \\
\hline$<1500 \mathrm{ml}$ & 27 & 96,4 & 1 & 3,6 & 28 & 87,5 & 0,003 & $(3,963-1655,753)$ \\
\hline$>1500 \mathrm{ml}$ & 1 & 25 & 3 & 75 & 4 & 12,5 & & \\
\hline Lama Duduk saat bekerja & & & & & & & & $27,000(1,646-$ \\
\hline$>4 \mathrm{jam} / \mathrm{hari}$ & 27 & 93,1 & 2 & 6,9 & 29 & 90,6 & 0,035 & $422.833)$ \\
\hline$<4 \mathrm{jam} / \mathrm{hari}$ & 1 & 33,3 & 2 & 66,7 & 3 & 9,4 & & \\
\hline Obesitas & & & & & & & & 81,000 \\
\hline$>25$, obesitas & 27 & 96,4 & 1 & 3,6 & 28 & 87,5 & 0,003 & $(3,963-1655,753)$ \\
\hline$<25$, tidak obesitas & 1 & 25 & 3 & 75 & 4 & 12,5 & & \\
\hline
\end{tabular}

Berdasarkan tabel 2 dapat dijelaskan bahwa dari hasil analisis hubungan usia, jenis kelamin, riwayat keluarga, intake cairan, lama duduk saat bekerja, dan obesitas menunjukka ada hubungan dengan kejadian penyakit batu saluran kemih. Hasil uji Chi-square terhadap semua variabel di dapat nilai p value $<0,05$.

\section{Hubungan Usia Dengan Kejadian Batu Saluran Kemih}

Berdasarkan hasil penelitian menunjukkan bahwa hasil analisis hubungan antara usia dengan kejadian batu saluran kemih diperoleh bahwa kejadian batu saluran kemih lebih besar pada kelompok lansia awal - manula yaitu 96,4\%. Hasil uji statistik diperoleh nilai p value 0,003 dapat disimpulkan ada hubungan yang bemakna antara usia dengan kejadian batu saluran kemih pada pasien di Ruang Poli Urologi RSAU dr. Esnawan Antariksa. Dari hasil analisis diperoleh nilai OR 81,000 artinya usia lansia awal - manula berpeluang untuk menderita batu 
saluran kemih sebesar 81 kali dibandingkan dewasa awal -dewasa akhir. Secara umum hal ini terjadi karena proses metabolisme yang sudah mulai menurun.

\section{Hubungan Jenis Kelamin Dengan Kejadian Batu Saluran Kemih}

Hasil analisis hubungan antara jenis kelamin dengan kejadian batu saluran kemih diperoleh bahwa kejadian batu saluran kemih lebih besar pada kelompok laki - laki yaitu 93,1\%. Hasil uji statistik diperoleh nilai $\mathrm{p}$ value 0,035 dapat disimpulkan ada hubungan yang bemakna antara jenis kelamin dengan kejadian batu saluran kemih pada pasien di Ruang Poli Urologi RSAU dr. Esnawan Antariksa. Dari hasil analisis diperoleh nilai OR 27,000 artinya kelompok laki - laki berpeluang untuk menderita batu saluran kemih sebesar 27 kali dibandingkan kelompok perempuan. Hal ini dipengaruhi oleh serum testosteron akan menghasilkan peningkatan produksi oksalat endogen oleh hati, rendahnya serum testosteron pada perempuan dan anak-anak menyebabkan rendahnya kejadan batu saluran kemih pada perempuan dan anak-anak, serta gaya hidup yang kurang baik pada laki-laki

\section{Hubungan Riwayat Keluarga Dengan Kejadian Batu Saluran Kemih}

Hasil analisis hubungan antara riwayat keluarga dengan kejadian batu saluran kemih diperoleh bahwa kejadian batu saluran kemih lebih besar pada kelompok ada riwayat yaitu $96 \%$. Hasil uji statistik diperoleh nilai $\mathrm{p}$ value 0,025 dapat disimpulkan ada hubungan yang bemakna antara riwayat keluarga dengan kejadian batu saluran kemih pada pasien di Ruang Poli Urologi RSAU dr. Esnawan Antariksa. Dari hasil analisis diperoleh nilai OR 18,000 artinya kelompok ada riwayat berpeluang untuk menderita batu saluran kemih sebesar 18 kali dibandingkan kelompok tidak ada riwayat.

\section{Hubungan Intake Cairan Dengan Kejadian Batu Saluran Kemih}

Hasil analisis hubungan antara intake cairan dengan kejadian batu saluran kemih diperoleh bahwa kejadian batu saluran kemih lebih besar pada kelompok < $1500 \mathrm{ml}$ yaitu 96,4\%. Hasil uji statistik diperoleh nilai $\mathrm{p}$ value 0,003 dapat disimpulkan ada hubungan yang bemakna antara intake cairan dengan kejadian batu saluran kemih pada pasien di Ruang Poli Urologi RSAU dr. Esnawan Antariksa. Dari hasil analisis diperoleh nilai OR 81,000 artinya kelompok $<1500 \mathrm{ml}$ berpeluang untuk menderita batu saluran kemih sebesar 81 kali dibandingkan kelompok > $1500 \mathrm{ml}$. Hal ini di dukung oleh teori bahwa pembentukan batu dipengaruhi oleh faktor hidrasi (air yang masuk dalam tubuh). Pada orang dengan dehidrasi (kekurangan cairan tubuh) kronik dan asupan cairan kurang memiliki risiko tinggi terkena batu saluran kemih 


\section{Hubungan Lama Duduk Dengan Kejadian Batu Saluran Kemih}

Hasil analisis hubungan antara lama duduk saat bekerja dengan kejadian batu saluran kemih diperoleh bahwa kejadian batu saluran kemih lebih besar pada kelompok > 4 jam / hari yaitu 93,1\%. Hasil uji statistik diperoleh nilai p value 0,035 dapat disimpulkan ada hubungan yang bemakna antara lama duduk saat bekerja dengan kejadian batu saluran kemih pada pasien di Ruang Poli Urologi RSAU dr. Esnawan Antariksa. Dari hasil analisis diperoleh nilai OR 27,000 artinya kelompok > 4 jam / hari berpeluang untuk menderita batu saluran kemih sebesar 27 kali dibandingkan kelompok < 4 jam / hari. Hasil penelitian ini sejalan dengan penelitian sebelumnya dan sejalan dengan teori yang menyatakan bahwa pasien yang terlalu lama duduk akan mengalami pelepasan kalsium tulang ke darah, yang akan mengakibatkan memacu timbulnya hiperkalsemia batu dikarenakan adanya proses supersaturasi bahan pembentukan batu di dalam tubulus renalis yang akan merubah zona stabil saturasi rendah menjadi zona saturasi tinggi

\section{Hubungan Obesitas Dengan Kejadian Batu Saluran Kemih}

Hasil analisis hubungan antara obesitas dengan kejadian batu saluran kemih diperoleh bahwa kejadian batu saluran kemih lebih besar pada kelompok > 25, obesitas yaitu 96,4\%. Hasil uji statistik diperoleh nilai $\mathrm{p}$ value 0,003 dapat disimpulkan ada hubungan yang bemakna antara obesitas dengan kejadian batu saluran kemih pada pasien di Ruang Poli Urologi RSAU dr. Esnawan Antariksa. Dari hasil analisis diperoleh nilai OR 81,000 artinya kelompok > 25, obesitas berpeluang untuk menderita batu saluran kemih sebesar 81 kali dibandingkan kelompok $<25$, tidak obesitas. Hasil penelitian diatas sejalan dengan teori yang menerangkan bahwa obesitas merupakan suatu keadaan peningkatan lemak tubuh baik diseluruh tubuh maupun di bagian tertentu. Obesitas dapat ditentukan dengan pengukuran antropometri seperti IMT (Indeks Masa Tubuh), distribusi lemak tubuh/ persen lemak tubuh melalui pengukuran tebal lemak di bawah kulit. Dikatakan obese jika IMT $\geq 25 \mathrm{~kg} / \mathrm{m} 2$. Pada penelitian kasus batu kalsium oksalat yang idiopatik didapatkan hasil 59,2\% terkena kegemukan. Pada laki-laki yang berat badannya naik 15,9 kg dari berat badan waktu umur 21 tahun mempunyai RR 1,39. Pada wanita yang berat badannya naik $15,9 \mathrm{~kg}$ dari berat waktu berumur 18 tahun, RR 1,7. Hal ini disebabkan pada orang yang gemuk pH air kemih turun, kadar asam urat, oksalat dan kalsium naik. 


\section{KESIMPULAN}

Berdasarkan hasil penelitian dan pembahasan tentang faktor yag berhubungan dengan kejadian batu saluran kemih di poli urologi dapat disimpulkan bahwa usia, jenis kelamin, riwayat keluarga, intake cairan, lama duduk saat bekerja dan obesitas terdapat hubungan yang signifikan. Masyarakat diharapkan mampu memperhatikan pola hidup sehat (dll sesuai faktor resiko) untuk lebih mengetahui faktor yang mempengaruhi kejadian batu saluran kemih, serta petugas kesehatan diharapkan dapat melakukan promosi kesehatan tentang faktor resiko yang dapat mempengaruhi kejadian batu saluran kemih, sehingga pasien maupun keluarga mempunyai pengetahuan yang luas dan mempunyai motivasi tinggi untuk menghindari faktor resiko eksternal (riwayat, intake cairan, lama duduk saat bekerja, dan obesitas).

\section{REFERENSI}

1. Buntaram, M. A., dkk. (2014). Hubungan Angka Kejadian Batu Saluran Kemih pada Pasien Rawat Jalan Rumah Sakit Al-Islam Tahun 2014. Diakses pada 09 April 2017.

2. http:// karyailmiah.unisba.ac.id.

3. Hidayah, I.D., Nugroho, T., Widianto, A. (2013). Hubungan Lokasi Batu Ureter dengan Manifestasi Klinis pada Pasien Ureterolithiasis di RSKB AN NUR Yogyakarta, JKKI, Vol. 5, No. 2, Mei-Agustus 2013. Diakses pada 23 Mei 2017. http:// journal.uii.ac.id/index

4. Mehmed, M.M., \& Ender O., (2015). Effect of urinary stone disease and it's treatment on renal function. World J Nephrol: 4(2): 271-276

5. Nuari, N. A., \& Widayati, D. (2017). Gangguan Pada Sistem Perkemihan \& Penatalaksanaan Keperawatan. Yogyakarta: Deepublish Publisher.

6. Prabowo, E., \& Pranata, A.E. (2014). Buku Ajar Asuhan Keperawatan Sistem Perkemihan Pendekatan NANDA, NIC dan NOC. Yogyakarta: Nuha Medika.

7. Wardani, M. A. F., dkk. (2013). Hubungan Batu Saluran Kemih Dengan Penyakit Ginjal Kronik Di Rumah Sakit An-Nur Yogyakarta Periode 2012-2013. Mahasiswa Fakultas Kedokteran Universitas Muhammadiyah Surakarta. eprints.ums.ac.id

8. Wendi, M. (2016). Faktor-Faktor yang Berhubungan dengan Kejadian Batu Ginjal pada Pasien Laki-Laki di Ruang Poli Urologi RSUD Pasar Rebo Jakarta Timur. 